\title{
Some Thoughts on the Teaching Secretaries in Colleges and Universities at present
}

\author{
Yafei Li ${ }^{\mathrm{a}}$, Hongchang Wang ${ }^{\mathrm{b}}$ \\ Jilin Agricultural University, Changchun 130118, China. \\ a1378795091@qq.com, b731996930@qq.com
}

\begin{abstract}
As the executive of the university management, teaching secretary is mainly responsible for the basic level of teaching affairs, and plays an important role in the teaching management system. This paper makes an in-depth analysis of the current teaching secretary work on the basis of the functional requirements of teaching secretary. First of all, this paper makes a detailed introduction about the role orientation, basic functions and the main features of the teaching secretary; then, this paper analyzes the factors that affect the quality of teaching secretary; finally, this paper discusses how to do the teaching secretary work, and puts forward five specific thoughts.
\end{abstract}

Keywords: Teaching secretary; university management; thoughts.

\section{Introduction}

With the development of higher education, the management of colleges and universities has become the most important part of the higher education. As the most basic level of management staff, teaching secretary is the link between school leaders, teachers, and students. Teaching secretary's work attitude and work quality will directly affect the school teaching process. Therefore, this paper analyzes the function and the hot spot of the teaching secretary in University, and analyzes the factors that affect the quality of the work.

\section{The Basic Introduction of the Teaching Secretary in the Teaching Management}

\subsection{Role Positioning.}

The nature of the work of the teaching secretary should be located in both the management of the teaching work and the service to the teaching and management is essentially a service. Because the work of the entire school will eventually be implemented to serve the students. As a teaching secretary, this kind of service is more specific and more direct. The teaching secretary provides the service for the leadership of the Department, and serves for the student and the teacher's daily teaching. Teaching secretary needs to be a good staff and assistant of the leaders in the Department of the development of the annual teaching plan, the introduction of the teaching management measures, etc. The teaching secretary needs to provide some information and equipment needed for the teaching work in time, and it can also handle the teaching and learning of the students and provide support for the teaching and learning of the students.

\subsection{Basic Functions of Teaching Secretary.}

The specific contents of the basic functions of the teaching secretary are shown in Table 1 .

The specific introduction of these functions is as follows:

Service guarantee function: management is service, and the teaching secretary is engaged in the teaching administration, which is the regular management in the process of the teaching plan implementation, including the teaching operation management, teaching routine management and teaching file management. Its main purpose is to maintain the normal teaching order. The teaching secretary focuses on the service for teaching and the service for teachers and students, which is responsible for handling the specific teaching affairs and ensuring the development of the teaching activities from the beginning until the end of term.

Organization and coordination function: in addition to service support functions, the teaching secretary also has the function of organizing and coordinating, which means the teaching secretary is 
responsible for the organization of the College (Department) to implement the teaching work, such as ordering textbooks, teaching plan implementation, final examination, and graduates graduation qualification examination. At the same time, due to the many activities of the teaching management presents a crisscross network, the completion of the teaching task is accomplished by many departments. Teaching secretary is coordinated with the office of academic affairs, between the College (Department) and the staff room, the teachers and students relations, and plays a connecting link between the preceding and the following, reasonable co-ordination role.

Table.1 Structure diagram of speed loop of servo system

\begin{tabular}{|c|c|c|}
\hline Function & Function content & Service object \\
\hline $\begin{array}{l}\text { Service guarantee } \\
\text { function }\end{array}$ & $\begin{array}{l}\text { Maintain normal teaching order, deal with the } \\
\text { specific teaching affairs, and ensure the } \\
\text { development of teaching activities. }\end{array}$ & $\begin{array}{l}\text { Whole school teachers and } \\
\text { students }\end{array}$ \\
\hline $\begin{array}{l}\text { Organization and } \\
\text { coordination } \\
\text { function }\end{array}$ & $\begin{array}{c}\text { Organize the College (Department) to implement } \\
\text { the teaching work, such as ordering textbooks, } \\
\text { teaching plans, work and final graduation } \\
\text { qualification examination }\end{array}$ & $\begin{array}{l}\text { Office of academic affairs, } \\
\text { College (Department), } \\
\text { teaching and research } \\
\text { section, teachers, students }\end{array}$ \\
\hline $\begin{array}{l}\text { Inspection and } \\
\text { supervision } \\
\text { function }\end{array}$ & $\begin{array}{l}\text { Understand the teacher's teaching situation, } \\
\text { students' learning situation, and check the } \\
\text { implementation of supervision and teaching } \\
\text { aspects of the situation }\end{array}$ & Teachers and students \\
\hline $\begin{array}{c}\text { Advisory } \\
\text { feedback function }\end{array}$ & $\begin{array}{l}\text { Promote the various rules and regulations } \\
\text { formulated by the school or higher authorities to } \\
\text { the teachers and students. At the same time, it also } \\
\text { needs to ask and listen to their opinions and } \\
\text { suggestions, timely feedback to the College } \\
\text { (Department) leadership or teaching departments }\end{array}$ & $\begin{array}{l}\text { College (Department) } \\
\text { leaders, teaching } \\
\text { supervisors, teachers and } \\
\text { students }\end{array}$ \\
\hline
\end{tabular}

Inspection and supervision function: teaching secretary is the link between "teaching" and "learning". The teaching secretary needs to understand the teacher's teaching situation and the students' learning situation, and inspect and supervise the implementation of teaching links, so as to find the problems and deal with it in time to ensure the teaching quality and improve the teaching effect.

Advisory feedback function: In addition to the above three kinds of functions, the teaching secretary also has Advisory feedback function. The teaching secretary also needs to publicize the various rules and regulations of the school or the superior department in charge of the teachers and students, and convey documents on teaching management to the teachers and students, and take the initiative to seek and listen to their opinions and suggestions, timely feedback to the College (Department) leadership or teaching departments.

\subsection{The Main Features of the Teaching Secretary Work.}

The main characteristics of the work of teaching secretary can be summarized as 4 points, namely the auxiliary nature, the service nature, the comprehensive nature and the policy nature. The details are as follows:

(1) Auxiliary nature: the academic secretary is the staff and assistant of the College (Department) of the leaders. Therefore, the auxiliary is the basic characteristics of the teaching secretary work. School (Department) leadership work involves a lot of a multitude of specialized knowledge and technology. It is impossible for a leader to think everything in the round, so it requires the Secretary to help and remind. Therefore, the teaching secretary should have the function of consultation and compensation.

(2) Service nature: the teaching secretary is to provide quality service for the leaders and teachers and students, and needs to create a convenient condition for the leadership of the decision making work, thus improving the efficiency and quality of the work. Teaching secretary needs to provide services for the College (Department) departments, teachers and students. Only the teaching 
secretary put their heart and soul into the service for these three aspects, the successful completion of the teaching task of the College (Department) can be guaranteed.

(3) Comprehensive nature: the teaching secretary's work involves all the teaching work of the College (Department). It is not only to assist the leadership of the management of teaching, but also to deal with the specific issues of teaching. So the work of the teaching secretary is comprehensive.

(4) Policy nature: Any unit and any leader should implement the principles and policies of the party and the state. As an assistant, the teaching secretary's work is closely linked to the policy. Whether it is to assist the leadership or to do the text, work should conscientiously implement the relevant policies and regulations.

\section{Factors Affecting the Quality of Teaching Secretary and Its Analysis}

Factors affecting the quality of teaching secretary can be summarized as the following 4 points, which are shown in Table 2.

Table.2 Factors affecting the quality of teaching secretary

\begin{tabular}{|c|c|}
\hline Influencing factors & Main performance \\
\hline Personnel quality is not high & $\begin{array}{c}\text { Most of the teaching secretary's educational level is low, the } \\
\text { management level is not high, and the psychological quality is } \\
\text { low. }\end{array}$ \\
\hline Work has not been fully valued. & $\begin{array}{c}\text { Whether in the aspects of title, post, awards or in learning and } \\
\text { training, teaching secretary is less opportunity than classmate's } \\
\text { calendar. }\end{array}$ \\
\hline $\begin{array}{c}\text { Working procedures are not } \\
\text { standardized }\end{array}$ & $\begin{array}{c}\text { Teaching secretary often is in the "dilemma" of office affairs } \\
\text { and academic affairs. }\end{array}$ \\
\hline $\begin{array}{c}\text { Position, responsibility and power } \\
\text { are separated from each other }\end{array}$ & $\begin{array}{c}\text { Teaching secretary has the responsibility to the right, the } \\
\text { responsibility of the power cannot be unified, }\end{array}$ \\
\hline
\end{tabular}

The details of these factors are as follows:

(1) Quality needs to be improved: this is mainly manifested in the following aspects: 1) the education level is low. Most of the teaching secretary in the undergraduate education, and the overall cultural quality is not high. Their ability to express basic skills and language skills, the ability to operate computer is still very lacking. 2) Management level is not high. The teaching secretary knows little about the teaching management theory, and they cannot use the theory to guide the practice. In management, it still took over traditional experience and verbal type management mode, and still in a shallow level, extensive management, and the scientific management method and the method is lack. At the same time, most of the teaching secretary did not study the College (Department) professional, so that they do not understand the professional knowledge of the jurisdiction, so that they failed to play a very good feedback and planning. 3) Psychological quality is low. Because of the heavy duty and the big pressure, the treatment is relatively low, which makes the partial teaching secretary of the psychological imbalance, no enthusiasm for the work, cannot take the initiative to invest in the cause of teaching management.

(2) Work has not been fully valued. Because of the old ideas and the lack of the importance of education management and scientific understanding, some people think that the educational administration is some simple work. In the teaching secretary of the equipment, learning and training, the strength is far from enough. Whether in the aspects of title, post, awards or in learning and training, teaching secretary is less opportunity than classmate's calendar. This seriously hurt the enthusiasm of the work of teaching secretary, leading to the people think, the team is not stable.

(3) Working procedures are not standardized. Work procedures are in a certain order and method of work, and standardizing the working procedure is the key to improve the efficiency of the work. In administration, the teaching secretary is a College (Department), by the office management, in the business, it belongs to the academic affairs office, and it directly accepts the arrangement of the academic affairs office. For this purpose, the teaching secretary often is in the "dilemma" of the office 
affairs and the academic affairs.

(4) Position, responsibility and power are separated from each other. In the organization and management activities, duties, responsibilities and powers of the three conditions, and must match and balance. Position, responsibility and authority must match and balance the three. Study secretary is the basic level of teaching management staff, and they should have a certain level of management authority, but in fact, the teaching secretary has no right to be responsible. Duties and rights cannot be unified. They act as a "fireman" role, but they are just "doing things" not "managing things", so that the work is difficult to put in place.

\section{Some Thoughts on Doing the Work of Teaching Secretary at Present}

Colleges and universities should formulate relevant policies, and attach importance to the teaching secretary in the examination and promotion of the title and position. Colleges and universities should stabilize the teaching secretary team, improve the management level, and bring the construction of the teaching secretary as a whole into the school's teacher training program. We have made a thorough analysis on the present teaching secretary's work from the functional requirements of the teaching secretary. In this paper, we think that as long as the following points, we can effectively maintain the good operation of teaching order.

(1) Improve the quality of teaching secretary

To improve the quality of teaching secretary staff need to start from three aspects. First of all, are needs to improve the ideological and political quality of teaching secretary? The construction of colleges and universities should be placed in the first place in the political direction, if the teaching secretary has no good ideological and political quality, it is difficult to accurately grasp the educational policy and related policies of the party and the country. Moreover, it needs to improve the management level of teaching secretary. Finally, it needs to improve the comprehensive ability of teaching secretary.

(2) Strengthening the construction of teaching secretary team

To strengthen the construction of teaching secretary team, we need to do the following two points. First of all, the leadership should pay full attention to the teaching secretary team. School and relevant functional departments to raise awareness, and pay attention to the selection and training of teaching secretary. The leaders must fully affirm and evaluate the performance of the teaching secretary, and establish a reasonable evaluation mechanism, improve the teaching secretary's work status and treatment. The schools must carry out business training or seminars in a timely manner, and it needs to teaching secretary of on-the-job training and continuing education, let them learn about higher education curriculum management system.

(3) Strengthen the service consciousness, management consciousness and self-consciousness of teaching secretary

From the service content, service awareness is to do a good job in the three levels of service. One is serving the leadership, the two is for the teacher's teaching service, and the three is for the student's learning service. From the service point of view, to provide information services for the college leaders should be paid special attention. Teaching secretarial work is an important part of teaching administration, which plays a link between teaching and learning. In order to do a good job, teaching secretary must face the reality, strengthen management consciousness, and learn advanced management methods. The efficiency and attitude of the teaching secretary often directly reflects the quality and ability of the teaching secretary. Therefore, the teaching secretary must strengthen self-discipline consciousness; do their own work, to adapt to the needs of the development of the situation.

(4) Reform the management system, set up the new mode of teaching secretary management system

Institutions of higher learning should unify the teaching secretary to the educational administration office, and make the teaching secretary the same as the Department staff. The teaching secretary and teaching staff can cross each other in a certain period of time. This will not only help to 
deal with the relationship between the three parties of the educational administration department, College (Department) and teaching secretary, but also can improve the status of teaching secretary, to enhance their self-confidence. At the same time, to clarify the responsibilities of the teaching secretary and clarify the responsibilities of the teaching secretary would be able to free the teaching secretary from office affairs and concentrate on the management of teaching affairs.

(5) Strengthen management and set up the incentive mechanism of target competition

To carry out the post competitive activities of teaching secretary, and give recognition and reward to the teaching secretary who has a strong sense of responsibility, a high level of business and outstanding performance. This can effectively mobilize the enthusiasm of the teaching secretary's work, and promote the development of teaching management.

\section{Conclusion}

The comprehensive quality of college teaching secretary must be continuously promoted with the development of higher education. At the same time, colleges and universities must pay enough attention to the teaching secretary, and strengthen the service consciousness, management consciousness and self-discipline consciousness of teaching secretary. And the colleges and universities must also reform the management system, establish a new model of teaching secretary management system, and achieve the goal of the establishment of competitive incentive mechanism. Only in this way can we ensure the smooth running of teaching management work, and improve the teaching quality of colleges and Universities.

\section{References}

[1] $\mathrm{Yu} \mathrm{F}$. The role of teaching secretary in teaching management in the professional dance colleges and Universities [J]. Journal of Jiamusi Education Institute, 2013.

[2] Xing S Y. Analysis of Teaching Secretary's Work in the Teaching Management of Colleges and Universities [J]. Academic Journal of Shaolin \& Taiji, 2013.

[3] Wang X J, Management S O, University J C. Teaching Secretary Competency Model Construction at Teaching Management of Colleges and Universities [J]. Journal of Changchun Normal University, 2014.

[4] Cao X, Guo W, Duan Z, et al. Current situation and thoughts on the running of college students' innovative projects in Shanxi Medical University[J]. Basic Medical Education, 2014.

[5] Huang P. Talking about how to do well in the work of teaching secretary specialty in University [J]. Journal of Jiamusi Education Institute, 2012.

[6] Jia L. On the Status and Function of Educational Administrative Secretary in Departments of Colleges and Universities_-also the work about Managing files for educational administration [J]. Journal of Jiangsu Institute of Education, 2005.

[7] Xing S Y. Analysis of Teaching Secretary's Work in the Teaching Management of Colleges and Universities [J]. Academic Journal of Shaolin \& Taiji, 2013.

[8] Yu Y Y, Yu F. The role of teaching secretary in teaching management in the professional dance colleges and universities [J]. Journal of Jiamusi Education Institute, 2013.

[9] Bo K. Work of Teaching Secretary in Art Colleges and Universities [J]. Hundred Schools in Arts, 2012.

[10] Shi X Y. Talking about Several Work of Reinforcing Records Supervision in Colleges and Universities [J]. Journal of Tangshan Vocational \& Technical College, 2006. 